\title{
Judul : Pertumbuhan Penduduk dan Pendidikan di Indonesia
}

Metode $\quad: \underline{\text { Literasi }}$

Penulis : D. Wangbang. S

Instansi $\quad$ : SMA NEGERI 1 TAKISUNG

datwyabuddhi@yahoo.com

\begin{abstract}
Abstrak
Angaapan banyak anak banyak rizki merupakan cara berpikir masyarakat jaman dulu, dimana menurut mereka dengan banyak anak maka kehidupan perekonomian keluarga akan mengalami kenaikan tanpa memperhatikan pendidikan anak-anaknya.

Apakah pada jaman milenial anggapan tersebut masih bisa diterapkan?

Ternyata seiring waktu berkembang dan dibarengi dengan peristiwa ledakan penduduk yang sangat signifikan, anggapan tersebut berangsur-angsur mulai memudar dengan sendirinya.

Akan tetapi apakah dengan memudarnya nggapan tersebut dunia pendidikan menjadi lebih baik?

Sejak jaman orde baru (ORBA) sampai saat ini ternyata dunia pendidikan terus berbenah mencari dan terus mencari formula yang tepat dalam pencapaian visi dan misi Undang Undang Dasar 1945 pasal 1 menyatakan bahwa setiap warga negara berhak mendapat pendidikan. Dilanjutkan setiap warga negara wajib mengikuti pendidikan dasar dan pemerintah wajib membiayai yang tertuang pada pasal 2

Kurikulum merupakan kunci utama dalam dunia pendidikan seperti yang sudah kita ketahui semenjak kemerdekaan sudah sering kita ganti kurikulum hingga saat ini muncul kurikulum baru yaitu KURIKULUM DARURAT COVID 19.

Hal inilah yang membuat pendidikan kita tidak pernah habis kita bicarakan sampai kapanpun,karena dunia pendidikan akan berkembang menyesuaikan perkembangan jaman dan masyarakatnya.
\end{abstract}




\section{PENDAHULUAN}

Pertanggal 1 juli 2019 Indonesia menempati peringkat ke empat dengan jumlah penduduk tertinggi di dunia hingga mencapai sebesar 268.074.600 jiwa. Dengan banyaknya jumlah penduduk Indonesia sudah pasti banyak juga permasalahan yang dihadapi oleh pemerintahan Indonesia khususnya dalam bidang pendidikan.

Ujung tombak kemajuan suatu bangsa terletak pada pendidikan suatu bangsa, tingginya tingkat pendidikan masyarakat suatu bangsa, maka bangsa tersebut semakin disegani dan dihargai oleh bangsa lain.

Akan tetapi hal ini berbanding terbalik dengan kenyataan. Beberapa masyarakat masih beranggapan bahwa pendidikan merupakan sesuatu yang sepele, karena dengan belajar tidak membuat kita menjadi kaya, hal ini didukung dengan mahalnya biaya pendidikan saat ini sehingga mereka enggan untuk melajutkan studinya.

Tulisan ini menelaah hubungan antara pertumbuhan penduduk dan pendidikan. Apakah pertumbuhan penduduk mempengaruhi sistem pendidikan ataukah sistem pendidikan depengaruhi oleh pertumbuhan penduduk.

Didalam tulisan ini akan membahas masalah-masalah kependudukan di Indonesia. Dan dilanjutkan dengan keterkaitan antara pertumbuhan penduduk dengan pendidikan di Indonesia.

\section{PROBLEMATIKA KEPENDUDUKAN DI INDONESIA}

Dengan jumlah total penduduk Indonesia sekitar 268 juta jiwa, Indonesia menempati peringkat ke empat setelah Tiongkok, India, dan Amerika. Bahkan fenomena ini di dukung dengan data dari PBB bahwa pada tahun 2030 jumlah penduduk Indonesia akan mencapai 295 juta jiwa.

Faktor yang mempengaruhi pertumbuhan penduduk adalah Tingkat kelahiran yang cukup tinggi, Tingkat kematian yang rendah dan Perpindahan penduduk. 


\section{Komposisi Penduduk}

Jumlah penduduk Indonesia berdasarkan sensus tahun 2019 ber jumlah 265.015.300 jiwa, berdasarkan jumlah tersebut komposisi pendudk berdasarkan usia tidak seimbang sehingga dapat memunculkan masalah-masalah baru

Berikut adalah tabel komposisi jumlah penduduk berdasarkan usia :

\begin{tabular}{|l|l|}
\hline $\begin{array}{l}\text { Kelompok Umur } \\
\text { (th) }\end{array}$ & Jumlah \\
\hline $0-4$ & $23.729,6$ \\
\hline $5-9$ & $23.878,4$ \\
\hline $10-14$ & $22.878,7$ \\
\hline $15-19$ & $22.242,9$ \\
\hline $20-24$ & $21.283,3$ \\
\hline $25-29$ & $21.125,3$ \\
\hline $30-34$ & $20,258,3$ \\
\hline $35-39$ & $20.181,5$ \\
\hline
\end{tabular}

\begin{tabular}{|l|l|}
\hline $40-44$ & 19145,4 \\
\hline $45-49$ & 17375,4 \\
\hline $50-54$ & 15025,4 \\
\hline $55-59$ & 12326,6 \\
\hline $60-64$ & 9352,8 \\
\hline $65-69$ & 6365,9 \\
\hline $70-74$ & 4218,6 \\
\hline$>75$ & 4817,2 \\
\hline Jumlah & $\mathbf{2 6 5 0 1 5 , 3}$ \\
\hline
\end{tabular}

Tabel 1.0

Sumber : Badan Pusat Statistik

Angka-angka tersebut menunjukkan usia 0-4 tahun yang berjumlah 23.729,6 jiwa, 5-9 tahun berjumlah 23.878,4 jiwa dan 10-14 tahun sebesar 22.878,7 jiwa dimana rentang usia tersebut merupakan usia belum produktif.

Salah satu permasalahan yang dapat muncul akibat kondisi tersebut adalah bidang pendidikan, karena pendidikan memerlukan biaya yang tidak sedikit, yang mengakibatkan fasilitas pendidikan sangat sulit dipenuhi dan sehingga mengakibatkan kualitas pendidikan tersebut memiliki mutu yang kurang terjamin. 
Langkah - langkah pemecahan masalah tersebut diantaranya :

(a) Program Keluarga Berencana.

(b) Peningkatan masa pendidikan.

(c) Pembatasan usia pernikahan

\section{Permasalahan Kehamilan}

UU RI No.23 Tahun 2003 sudah jelas menjelaskan bahwa tingkat pendidikan seseorang dapat mendukung atau mempengaruhi tingkat pengetahuan yaitu semakin tinggi pengetahuan seseorang akan mempermudah ibu menerima informasi kesehatan tapi sebaliknya rendahnya pendidikan maka pengetahuan pun menjadi sangat terbatas sehingga acuh terhadap kesehatan. Faktor-faktor lainnya yang mendukung angka kelahiran adalah sebuah anggapan dari orang tua bahwa banyak anak banyak rejeki.

Usia merupakan unsur utama dalam mempengaruhi tingkat keberhasilan kehamilan, semakin tua umur seorang permpuan semakin beresiko dalam masa kehamilannya.

Undang-Undang Nomor 1 Tahun 2014 tentang Perkawinan yang berbunyi "Perkawinan hanya diizinkan apabila pria dan wanita sudah mencapai umur 19 (sembilan belas) tahun,"

\section{PENDIDIKAN DI INDONESIA}

Tingkat perekonomi yang rendah dapat berakibat pada tercukupinya atau tidaknya pemenuhan makanan yang dibutuhkan sehingga dapat mengakibatkan dampak yang lebih lanjut salah satunya kurang ketercukupan gizi (malnutrition). Pada gilirannya nanti bila kekurangan gizi terutama pada usia muda ( 0 -5 tahun). Akan mengganggu perkembangan otak bahkan dapat terbelakang mental ( mental retardation ). Sehingga akan berdampak terhadap mutu SDM dimasa yang akan datang.

Jumlah mahasiswa yang ada di seluruh Indonesia baik negeri maupun swasta sebanyak 1.768.510 orang, ini berarti setengah dari lulusan SMA/SMK yang melanjutkan ke jenjang Strata 1 Cuma 2.997.422 orang 
Dalam memperbaiki sistem pendidikan nasional pemerintah berusaha menentukan standarsasi pendidikan nasional. Kualitas pendidikan antara lain menghasilkan ujian nasional sebagai tolak ukur untuk menentukan nasib anak. Sehingga untuk mencegah rendahnya angka ketidaklulusan, maka beberapa mata pelajaran dikurangi jam belajarnya, diantaranya pendidikan Agama.

Begitu banyak pemberitaan yang menyajikan peristiwa-peristiwa kemerosotan moral,apalagi dalam dunia pendidikan. Dengan adanya berbagai peristiwa itu, kita yang bergerak dalam dunia pendidikan perlu melakukan instrospeksi dan bertanya mungkinkah kegagalan dunia pendidikan menjadi salah satu penyebab terjadinya degradasi moral tersebut? Pertanyaan semacam itu tentunya sah-sah saja disampaikan mengingat dunia pendidikan merupakan "kawah candradimuka" yang bertugas membangun intelektual, moral, dan keterampilan siswa sebagai calon warga atau pun pemimpin-pemimpin bangsa.

Pudarnya ataupun hilangnya modal sosial yang dimiliki oleh masyarakat menimbulkan masalah sosial. Perhatian seperti ini perlu diberikan sebagai solusi terutama dalam proses pendidikan yang sangat dibutuhkan agar peserta didik tidak melakukan perbuatan yang nantinya menjadi sebuah kebiasaan.

Ketika Orde Baru bermaksud menata kembali kehidupan berbangsa dan bernegara sesuai dengan Pancasila dan Undang-undang Dasar 1945, tujuan pendidikan nasional diarahkan untuk mendukung maksud tersebut. Tentu saja kurikulum sekolahan dikembangkan sesuai dengan tujuan pendidikan nasional. Kurikulum 1968 yang berlaku pada awal masa Orde baru kemudian mengalami pergantian menjadi kurikulum 1975, kurikulum sejarah juga mengalami penyempurnaan. Demikian seterusnya terjadi beberapa kali perubahan kurikulum menjadi kurikulum 1984, 1994 dan 2004 (yang akhir-akhir ini sempat diperbincangkan).(Umasih, 2006)

Rancangan yang memuat seperangkat mata pelajaran dan atau materinya yang akan dipelajari, atau yang akan diajarkan guru kepada siswa selanjutnya disebut dengan kurikulum.

Hal ini berbanding terbalik dengan pandangan kurikulum dari siswa dan orang tua, bagi seorang siswa kurikulum cenderung memiliki makna adanya tugas pelajaran, latihan atau isi buku pelajaran. Sedangkan orang tuapun mengartikan kurikulum sebagai latihan atau pekerjaan rumah bagi anaknya. Hal tersebut menunjukkan adanya perbedaan arti dari 
kurikulum. Brady \& kennedy (2007:4) Perubahan zaman dan tuntutan kemajuan serta perbedaan persepsi atau pandangan filosofislah yang dapat merubah kurikulum.

\section{KESIMPULAN}

Pendidikan dan kurikulum tidak bisa dipisahkan, dua hal tersebut bisa berubah seiring dengan perkembangan ataupun pertumbuhan masyarakat. Dimana ilmu sudah berkembang dari zaman yunani yang bermula dari sebuah asumsi, hingga berkembang sampai saat ini berupa ilmu pengetahuan. 


\section{DAFTAR PUSTAKA}

https://www.kompasiana.com/ardiperdana

https://www.bps.go.id/indikator/indikator/view_data_pub

Putri, V. S., \& Oktora, S. I. (2020). DETERMINAN STATUS UNMET NEED FOR LIMITING BIRTH PADA WANITA USIA SUBUR BERSTATUS KAWIN DI JAWA BARAT TAHUN 2017. Jurnal Kependudukan Indonesia, 15(1), 85-102.

https://www.liputan6.com/health/read/4094188

https://pddikti.kemdikbud.go.id/publikasi

http://publikasi.data.kemdikbud.go.id/uploadDir

https://pddikti.kemdikbud.go.id/publikasi

Alfian, M. (2011). Pendidikan Sejarah dan Permasalahan yang dihadapi. Khazanah Pendidikan, 3(2).

Abbas, E. W. (2014). Pendidikan Karakter.

Mutiani, M. (2019). SOCIAL CAPITAL DAN TANTANGAN ABAD 21: Kontrubusi Pendidikan IPS dan Eksplorasi Nilai Sosial melalui Biografi KH Zainal Ilmi. SOSIODIDAKTIKA: Social Science Education Journal, 6(1).

https://books.google.co.id/books?hl=id\&lr=\&id=Rm_IDwAAQBAJ\&oi=fnd\&pg=PP1\&dq=k enapa+kurikulum+berubah\&ots=umnrq9N3yj\&sig=rde23z3IZiDvtHpcbiNP6ESPfjs\&redir_e $\mathrm{sc}=\mathrm{y} \# \mathrm{v}=$ onepage $\& \mathrm{q} \& \mathrm{f}=$ false 